\title{
Ograniczona wartość poznawcza finansów jednostek samorządu terytorialnego ${ }^{1}$
}

\section{Limited cognitive value of budgets and budget reporting of local government units}

\section{Streszczenie:}

Ekonomia jest nauką, od której oczekuje się dużej precyzji oraz konkretnych odpowiedzi dotyczących istoty otaczającej nas rzeczywistości gospodarczej, jak również zdolności predykcyjnych. Jest ona również nauką bazującą na badaniu pewnych regularności i prawidłowości. W warunkach dynamizacji przemian narastają trudności w ich identyfikowaniu, co przemawia za zmianą podejścia na rzecz analizy jakościowej. Trzeba więc poszukiwać języka, procedur badawczych oraz modeli umożliwiających pokazanie wszystkich stron działania gospodarki i jej składowych we wszystkich wymiarach bytu ludzkiego - zarówno w odniesieniu do zmian ilościowych, jak i jakościowych. Miary zjawisk ekonomicznych mają swoje wady oraz mogą być podatne na interpretacyjne manipulacje. Trzeba mieć więc nie tylko techniczne umiejętności obracania statystykami, lecz również wiedzieć, co się widzi. Celem niniejszego opracowania jest wskazanie niedoskonałości danych ilościowych zawartych w budżetach oraz sprawozdawczości budżetowej jednostek samorządu terytorialnego.

Słowa kluczowe: finanse publiczne, jednostki samorządu terytorialnego

\footnotetext{
1 Tekst wygłoszony podczas konferencji pt. Ekonomiczno-społeczne i organizacyjno-techniczne determinanty zarządzania rozwojem lokalnym w Wałczu dnia 9 września 2016 roku.
} 
Daniel Jurewicz - Ograniczona wartość poznawcza finansów...

\begin{abstract}
:
Economics is a science that expects high precision and concrete responses to the essence of the economic reality surrounding us as well as predictive capabilities. It is also a science based on the study of certain regularities and regularities. With the dynamics of change, the difficulty in identifying them is growing, which is in favor of a change in approach to qualitative analysis. Therefore, it is necessary to look for language, research procedures and models to show all sides of the economy and its components in all dimensions of human existence - both quantitative and qualitative. Measures of economic phenomena have their drawbacks and may be susceptible to interpretative manipulations. So you have to have not only the technical ability to turn statistics, but also know what you see. The purpose of this paper is to indicate the imperfection of quantitative data included in budgets and budget reporting of local government units.
\end{abstract}

Keywords: public finance, local government

\title{
Wprowadzenie
}

Ekonomia jest nauką, od której oczekuje się dużej precyzji oraz konkretnych odpowiedzi dotyczących istoty otaczającej nas rzeczywistości gospodarczej, jak również zdolności predykcyjnych². Jest ona również nauką bazującą na badaniu pewnych regularności i prawidłowości. W warunkach dynamizacji przemian narastają trudności w ich identyfikowaniu, co przemawia za zmianą podejścia na rzecz analizy jakościowej3. Trzeba więc poszukiwać języka, procedur badawczych oraz modeli umożliwiających pokazanie wszystkich stron działania gospodarki i jej składowych we wszystkich wymiarach bytu ludzkiego - zarówno w odniesieniu do zmian ilościowych, jak i jakościowych". Miary zjawisk ekonomicznych mają swoje wady oraz mogą być podatne na interpretacyjne manipulacje. Trzeba mieć więc nie tylko tech-

2 M. Ratajczak, Ekonomia $w$ dobie finansyzacji gospodarki, „Ruch Prawniczy, Ekonomiczny i Socjologiczny" 2014, nr 2, s. 263.

3 E. Mączyńska, Ekonomia w warunkach gospodarki nietrwałości, „Biuletyn PTE” 2011, nr 2, s. 40.

${ }^{4}$ M. G. Woźniak, O niektórych problemach współczesnego człowieka, ekonomii i systemów ekonomicznych w kontekście integracji procesów rozwojowych, „Nierówności Społeczne a Wzrost Gospodarczy" 2015, nr 41, s. 202-203. 
niczne umiejętności obracania statystykami, lecz również wiedzieć, co się widzi ${ }^{5}$.

Celem niniejszego opracowania jest wskazanie niedoskonałości danych ilościowych zawartych w budżetach oraz sprawozdawczości budżetowej jednostek samorządu terytorialnego. Znaczna część badaczy finansów samorządów lokalnych i regionalnych analizuje bowiem przede wszystkim dane pochodzące ze wskazanych źródeł. 0 wyborze tematyki zadecydowało przeświadczenie istnienia dużych luk na tym polu badawczym. Zdecydowanie aplikacyjny charakter opracowania miał kluczowy wpływ na jego strukturę. Po krótkim wprowadzeniu o charakterze teoriopoznawczym autor zaprezentował wyniki badań, które sam przeprowadził, jak też przywołał wyniki badań funkcjonujących już w przestrzeni publicznej. Opracowanie kończy podsumowanie zawierające najważniejsze wnioski.

\section{Realizacja zadań przez jednostki samorządu terytorialnego}

Proces reformowania finansów publicznych, odzwierciedlony w regulacjach kolejnych ustaw o finansach publicznych, to przede wszystkim działania w zakresie konsolidacji fiskalnej6. To jednak również działania w zakresie konsolidacji instytucjonalnej ${ }^{7}$, obejmującej zmiany zakresu oraz organizacji sektora finansów publicznych. Działania w obu tych zakresach są ze sobą sprzężone, a ich skutkiem ma być między innymi większa przejrzystość oraz mniejsze rozproszenie środków publicznych. Drugi ze wskazanych aspektów konsolidacji finansów publicznych dość rzadko poruszany jest w literaturze przed-

${ }^{5}$ G.W. Kołodko, Społeczne i przestrzenne aspekty zróżnicowania dochodów we współczesnym świecie, „Nierówności Społeczne a Wzrost Gospodarczy” 2014, nr 39, s. 33.

6 Więcej na temat tego aspektu konsolidacji zob. W. Ziółkowska, Wybrane aspekty konsolidacji fiskalnej $w$ sektorze general government, „Finanse, Rynki Finansowe, Ubezpieczenia" 2016, nr 6, cz. 2, s. 5-16.

7 B. Pietrzak, B. Woźniak, Instytucjonalne aspekty konsolidacji finansów publicznych, „Zeszyty Naukowe Uniwersytetu Ekonomicznego w Krakowie” 2014, nr 8, s. 94. 
Daniel Jurewicz - Ograniczona wartość poznawcza finansów...

miotu, pomimo że ma duże znaczenie dla pomiaru zjawisk związanych z finansami publicznymi.

Zakres podmiotowy sektora finansów publicznych określony jest, począwszy od 1999 roku, w kolejnych ustawach o finansach publicznych. Efektem konsolidacji instytucjonalnej jest, w dużym uproszczeniu, ograniczanie dostępnych form realizowania zadań publicznych. Na rysunku 1 zaprezentowano formy, za pośrednictwem których jednostki samorządu terytorialnego realizują zadania publiczne.

Rysunek 1. Zadania publiczne realizowane przez jednostki samorządu terytorialnego

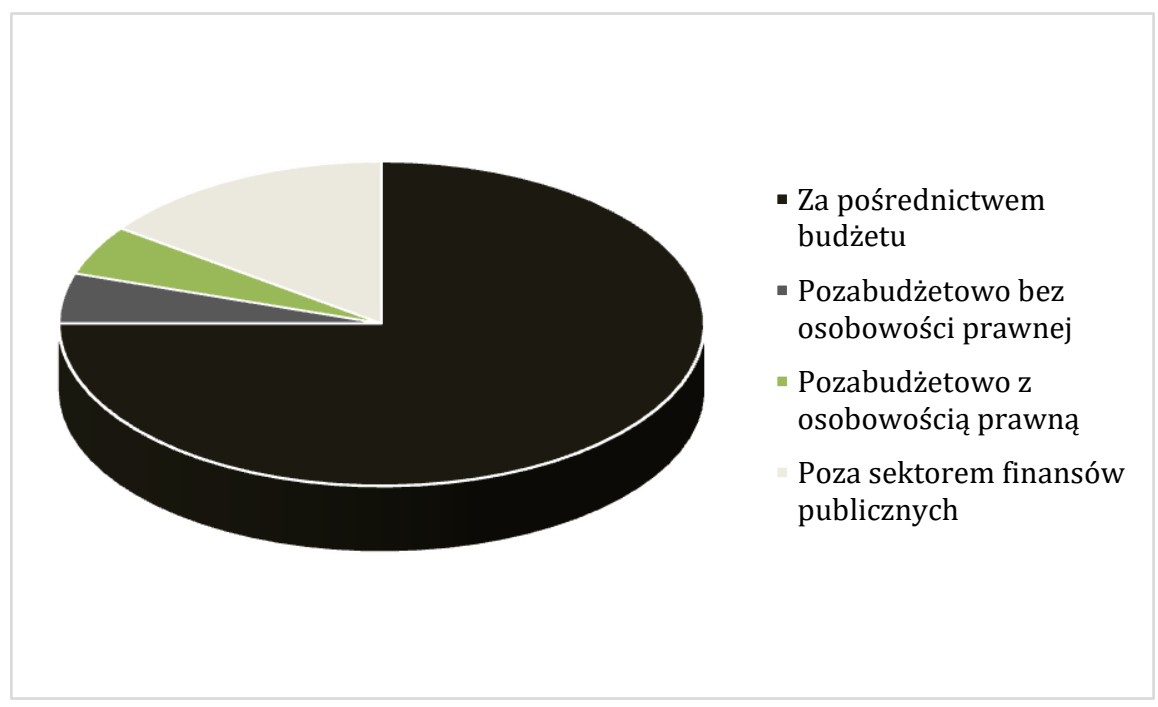

Źródło: opracowanie własne

O formie realizacji konkretnych zadań publicznych decydują przede wszystkim zapisy obowiązującego prawa, niemniej jednostki samorządu terytorialnego mają $\mathrm{w}$ tym zakresie dość znaczny zakres swobody. Ze względu na ograniczony charakter publikacji, jak też cel przyświecający jego powstaniu, niemożliwe są dogłębne rozważania w tym zakresie, niemniej konieczne jest przybliżenie podstawowych informacji. 
Zdecydowana większość zadań publicznych realizowanych jest za pośrednictwem jednostek budżetowych (w tym urzędów gmin i miast, starostw powiatowych oraz urzędów marszałkowskich). Wszystkie tak realizowane zadania ujmowane są w budżetach jednostek samorządu terytorialnego, które zawierają również zdefiniowane w ustawie o finansach publicznych przychody oraz rozchody budżetowe (które w zdecydowanej większości związane są ze zwrotnymi źródłami finansowania - a więc długiem publicznym). Część zadań realizowanych jest przez polskie samorządy za pośrednictwem należących do sektora finansów publicznych jednostek zarówno nieposiadających, jak też posiadających osobowość prawną. Do pierwszej z nich w obowiązującym stanie prawnym zaliczane są samorządowe zakłady budżetowe oraz wyodrębnione rachunki bankowe działające przy placówkach oświatowych. W okresach obowiązywania poprzednich ustaw o finansach publicznych były to zakłady budżetowe, samorządowe fundusze celowe, gospodarstwa pomocnicze jednostek budżetowych, środki specjalne oraz rachunki dochodów własnych. Ponadto część zadań realizują jednostki należące do sektora finansów publicznych wyposażone w osobowość prawną. Należą do nich samodzielne publiczne zakłady opieki zdrowotnej, samorządowe instytucje kultury oraz pozostałe osoby prawne tworzone na podstawie odrębnych ustaw (m. in. wojewódzkie fundusze ochrony środowiska i gospodarki wodnej, wojewódzkie ośrodki ruchu drogowego, ośrodki doradztwa rolniczego). Pozabudżetowe formy realizacji zadań publicznych nie znajdują swego odzwierciedlenia w budżetach, niemniej wybrane informacje o ich działalności ujmowane są w statystyce publicznej, w tym sprawozdawczości budżetowej. Część zadań publicznych realizują również jednostki nienależące do sektora finansów publicznych przede wszystkim spółki komunalne. Dane finansowe ich dotyczące, nawet gdy spółki stanowią w 100\% własność komunalną, znajdują się poza statystyką publiczną. 
Daniel Jurewicz - Ograniczona wartość poznawcza finansów...

Postępujący proces globalizacji gospodarki uwypuklił potrzebę harmonizacji i standaryzacji rachunkowości8. Skutkiem dążenia do ujednolicenia rachunkowości w sektorze publicznym są Międzynarodowe Standardy Rachunkowości Sektora Publicznego ${ }^{9}$. Standardy te nie zostały jednakże w pełni wdrożone przez Państwa Członkowskie Unii Europejskiej. Specyfiką Polski, jak też większości państw Unii Europejskiej, jest obowiązująca w rachunkowości budżetowej zasada kasowa, która nie zapewnia dostarczenia rzetelnych i wiarygodnych informacji10.

Kolejne zmiany ustawy o finansach publicznych, jak też innych aktów prawnych, powodują zmiany w zakresie form realizacji zadań publicznych. Może to znacząco utrudniać pomiar operacji gospodarczych związanych z finansami publicznymi, w tym finansami jednostek samorządu terytorialnego. Rozproszenie środków publicznych między różne formy działalności nie służy racjonalnemu wykorzystaniu, utrudniona jest również ich kontrola11.

\section{Wybrane elementy pozabudżetowej działalności jednostek samorządu terytorialnego z terenu województwa kujawsko- pomorskiego}

Piszący te słowa przeprowadził badanie skali działań realizowanych $\mathrm{w}$ formie pozabudżetowej bez osobowości prawnej przez wszystkie jednostki samorządu terytorialnego województwa kujawsko-pomorskiego według stanu na koniec 2004 oraz 2015 roku. Na koniec 2004 roku były to zakłady budżetowe, samorządowe fundusze celowe, gospodarstwa pomocnicze jednostek budżetowych oraz środki specjalne; na koniec 2015 roku - samorządowe zakłady budżetowe

\footnotetext{
${ }^{8} \mathrm{~K}$. Tkocz-Wolny, Harmonizacja i standaryzacja rachunkowości sektora publicznego, „Finanse, Rynki Finansowe, Ubezpieczenia” 2016 nr 4, s. 842.

9 Ibidem, s. 844.

10 M. Wakuła, Standaryzacja rachunkowości budżetowej, „Finanse, Rynki Finansowe, Ubezpieczenia" 2016, nr 2, s. 236.

11 B. Pietrzak, B. Woźniak, Instytucjonalne ..., op. cit., s. 108.
} 
oraz wyodrębnione rachunki bankowe działające przy placówkach oświatowych. Badaniu poddano jeden samorząd województwa, 19 powiatów oraz 144 gminy, w tym 4 miasta na prawach powiatu, 13 gmin miejskich, 35 gmin miejsko-wiejskich oraz 92 gminy wiejskie. Na rysunku 2 oraz 3 (na dalszych stronach) zaprezentowano wysokość środków finansowych zgromadzonych przez wskazane formy organizacyjno-prawne, odpowiednio dla 2004 roku oraz 2015 roku, wraz z porównaniem, jak znacząca była to kwota w porównaniu do wielkości dochodów budżetów badanych jednostek. W celu wyeliminowania czynnika zmiany wartości pieniądza w czasie dane zostały skorygowane o inflację 12 i wszystkie dane zostały sprowadzone do poziomu cen w 2015 roku. Wyniki dotyczą, licząc od początku układu współrzędnych, odpowiednio województwa samorządowego, powiatów oraz gmin.

Z danych wynika, że wskazany proces konsolidacji instytucjonalnej sektora finansów publicznych postępuje - ilość środków finansowych gromadzonych przez nieposiadające osobowości prawnej pozabudżetowe formy organizacyjne należące do sektora finansów publicznych w stosunku do budżetów samorządowych wyraźnie maleje na wszystkich szczeblach samorządów. Niemniej za nieuprawnione uznać należy twierdzenie, że wszystkie zadania realizowane przez pozabudżetowe formy ujmowane są obecnie w budżetach jednostkach samorządu terytorialnego. Część z nich realizowana jest bowiem przez komunalne spółki prawa handlowego. Nie da się niestety precyzyjnie ustalić, jaka część tych zadań realizowana jest poza sektorem finansów publicznych.

12 Dane w zakresie inflacji zaczerpnięto z informacji prezentowanych przez Główny Urząd Statystyczny - http://stat.gov.pl. 
Daniel Jurewicz - Ograniczona wartość poznawcza finansów...

Rysunek 2. Dochody budżetów jednostek samorządu terytorialnego oraz należących do nich zakładów budżetowych, gospodarstw pomocniczych, środków specjalnych oraz funduszy celowych $\mathrm{z}$ terenu województwa kujawsko-pomorskiego w 2004 roku

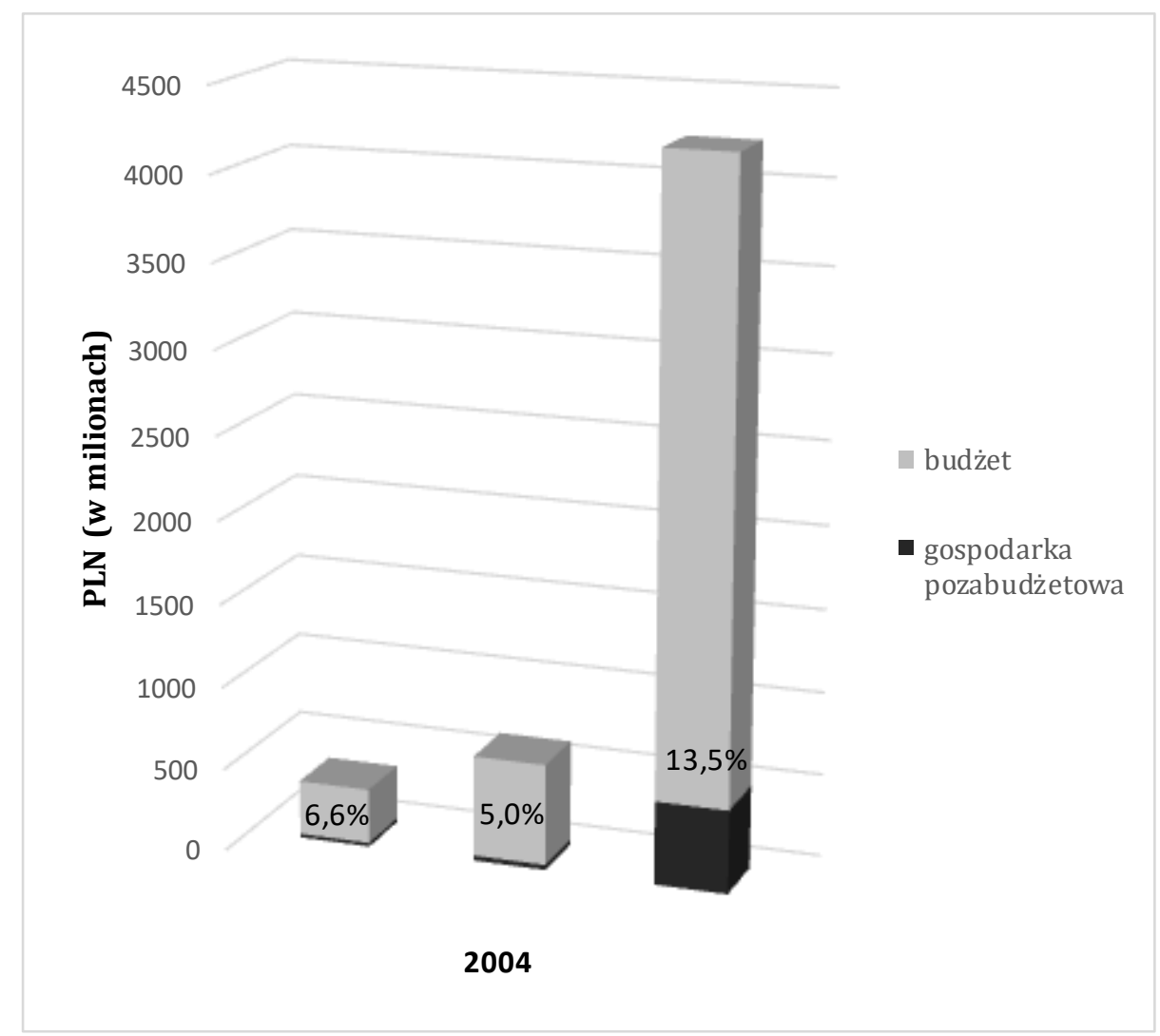

Źródło: opracowanie własne 
Rysunek 3. Dochody budżetów jednostek samorządu terytorialnego oraz należących do nich samorządowych zakładów budżetowych oraz wyodrębnionych rachunków dochodów jednostek oświatowych z terenu województwa kujawsko-pomorskiego w 2015 roku

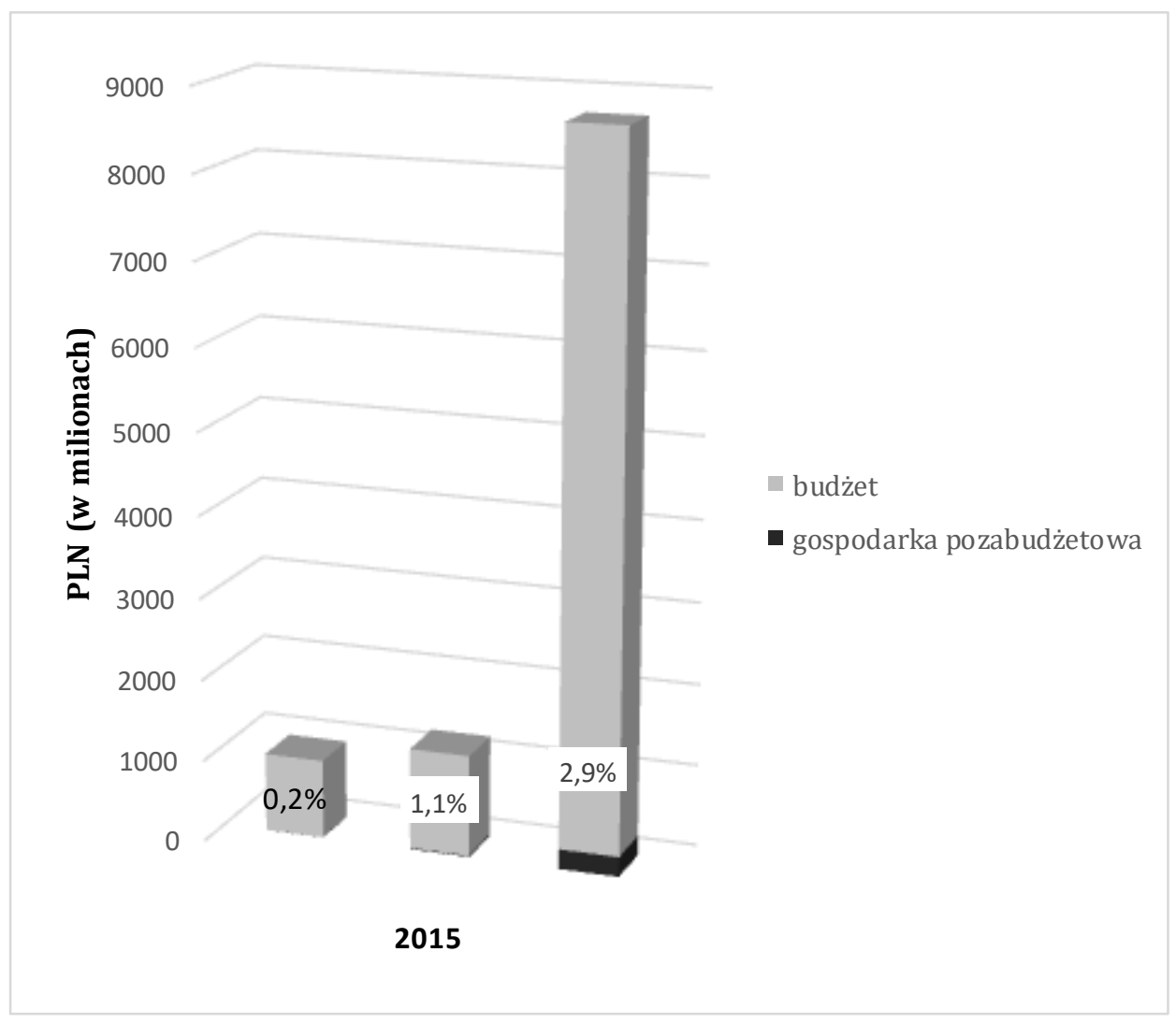

Źródło: opracowanie własne 
Daniel Jurewicz - Ograniczona wartość poznawcza finansów...

\section{Wybrane aspekty związane ze spółkami komunalnymi}

W 2014 roku firma Curulis opublikowała raport „Kondycja finansowa spółek komunalnych w Polsce" ${ }^{13}$. Z raportu wynika, że na koniec 2009 roku w podsektorze samorządowym funkcjonowało 1571 zakładów budżetowych, liczba samorządowych zakładów budżetowych na koniec 2012 roku wynosiła zaś 796. Potwierdza to wnioski wynikające $\mathrm{z}$ danych zawartych na rysunkach 2 i 3 . Znaczące zmniejszenie liczby zakładów budżetowych połączone było jednak ze znacznym wzrostem ilości spółek komunalnych. W tym samym okresie ilość spółek komunalnych działających $\mathrm{w}$ formie spółek $\mathrm{z}$ ograniczoną odpowiedzialnością wzrosła bowiem z 1933 do 2402, ponadto liczba spółek komunalnych działających w formie spółek akcyjnych wzrosła ze 180 do 409.

We wskazanym raporcie dokonano również próby oszacowania zadłużenia spółek komunalnych na podstawie ich sprawozdań finansowych. Z szacunków tych wynika, że na koniec 2012 roku w 12 wybranych miastach wojewódzkich zadłużenie spółek komunalnych wyniosło $32,4 \%$ zadłużenia tych miast. Również badania przeprowadzone przez A. Babczuka ${ }^{14}$ wskazują, że zadłużenie spółek komunalnych ma istotne znaczenie i może negatywnie wpływać na sytuację samorządów. W grupie poddanej badaniu na koniec 2010 roku jedynie $76 \%$ zadłużenia związanego z samorządami dotyczyło jednostek samorządu terytorialnego, ponadto $18 \%$ stanowiły zobowiązania spółek komunalnych. Zadłużenie jednostek organizacyjnych należących do sektora finansów publicznych stanowiło w tym okresie prawie $6 \%$ ogółu zadłużenia. W obowiązującym stanie prawnym zadłużenie spółek komunalnych nie podlega ograniczeniom ustawowym, ponadto próby badania jego wielkości i struktury są wyraźnie utrudnione. Znaczna część przedsięwzięć o charakterze inwestycyjnym samorządów terytorialnych realizowana jest przez komunalne spółki

\footnotetext{
${ }^{13}$ Curulis, Kondycja finansowa spółek komunalnych w Polsce, http:/curulis.pl, 2014.

${ }^{14}$ A. Babczuk, Zadłużenie spółek komunalnych w Polsce. Próba oceny skali i zróżnicowania regionalnego, „Finanse Komunalne” 2012, nr 9, s. 5-16.
} 
prawa handlowego, podobnie jak dług, nie są one ujmowane w oficjalnych statystykach. Z przeprowadzonych badań wynika, że około $25 \%$ wydatków inwestycyjnych miast wojewódzkich dokonywana jest z pominięciem budżetu, w odniesieniu do pozostałych miast na prawach powiatu jest to około $20 \%$ realizowanych wydatków inwestycyjnych ${ }^{15}$.

\section{Samodzielne publiczne zakłady opieki zdrowotnej}

Dług publiczny związany z jednostkami samorządu terytorialnego to przede wszystkim zobowiązania samych JST i ich związków stanowiące na przestrzeni ostatnich lat około 95\% całej kwoty tego zadłużenia16. Pozostałą część zadłużenia stanowią głównie zobowiązania samodzielnych publicznych zakładów opieki zdrowotnej. Znaczna część długu, niestety istnieje obawa, że nikt dokładnie nie wie jaka, związanego z samorządowymi szpitalami została przetransferowana poza sektor finansów publicznych poprzez spółki specjalnego przeznaczenia ${ }^{17}$. Nawet to oficjalnie wykazywane zadłużenie samorządowych samodzielnych publicznych zakładów opieki zdrowotnej może jednak bardzo mocno zmieniać optykę zadłużenia samorządowego. Na rysunku 4 zaprezentowano zadłużenie miast na prawach powiatu województwa kujawsko-pomorskiego (alfabetycznie - Bydgoszczy, Grudziądza Torunia oraz Włocławka) jako część dochodów tych miast oraz zadłużenie wskazanych miast po doliczeniu zadłużenia samorządowych osób prawnych należących do sektora finansów publicznych (a więc przede wszystkim samodzielnych publicznych zakładów opieki zdrowotnej) według stanu na koniec 2015 roku.

15 J. Czempas, Skłonność jednostek samorzqdu terytorialnego do inwestowania. Ujęcie ilościowe na przykładzie miast na prawach powiatu województwa ślq̨skiego, Katowice 2013, s. 177.

16 Ministerstwo Finansów, Zadłużenie Sektora Finansów Publicznych, Biuletyny Kwartalne za lata 2003-2013,

17 A. Kamela-Sowińska, Sekurytyzacja jako metoda oddłużenia polskich szpitali, „Finanse, Rynki Finansowe, Ubezpieczenia" 2014, nr 67, s. 911. 
Daniel Jurewicz - Ograniczona wartość poznawcza finansów...

Rysunek 4. Poziom zadłużenia jako część dochodów miast na prawach powiatu z terenu województwa kujawsko-pomorskiego oraz po doliczeniu zadłużenia pozostałych osób prawnych należących do sektora finansów publicznych (w \%) na koniec 2015 roku

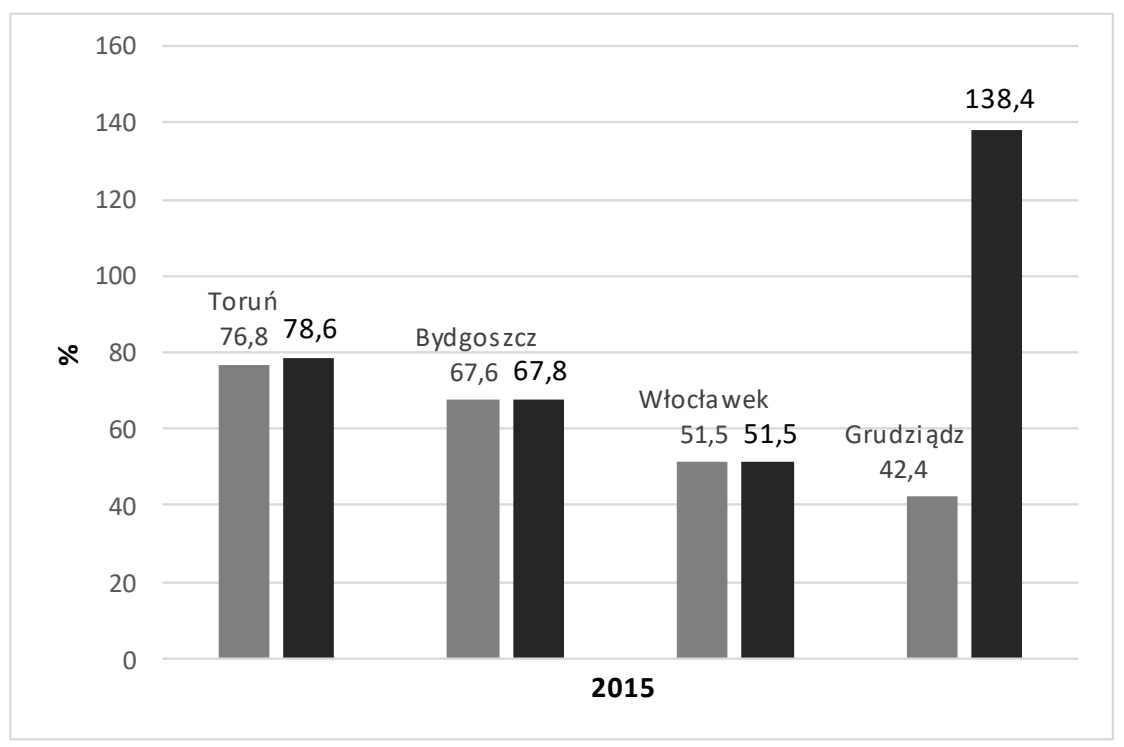

Źródło: opracowanie własne

Ogromny wzrost zadłużenia w przypadku samorządu miasta Grudziądza to efekt długu Regionalnego Szpitala Specjalistycznego im. dr. Wł. Biegańskiego w Grudziądzu, najbardziej zadłużonego szpitala publicznego w Polsce. Jest to doskonały przykład, że od tego, którą wielkość będziemy porównywać, zależały będą wyniki badań i porównań. Zadłużenie wskazanego szpitala jest również potwierdzeniem tezy, iż znaczna część długu publicznych szpitali znajduje się poza statystyką publiczną. W grudniu 2016 roku organy Miasta Grudziądza rozpoczęły bowiem proces wyprowadzania długu szpitala do spółki specjalnego przeznaczenia - Grudziądzkich Inwestycji Medycznych. W wyniku tego procesu już na koniec 2016 roku zadłużenie publiczne 
związane z Miastem Grudziądz znacząco spadło - zostało bowiem wytransferowane poza sektor finansów publicznych. Dane ilościowe w zakresie zadłużenia znacząco obniżyły się, co nie miało niestety żadnego związku z poprawą sytuacji finansowej miasta. W tabeli 1 przedstawiono szczegółowe dane ilościowe w zakresie zadłużenia Miasta Grudziądza oraz Regionalnego Szpitala Specjalistycznego im. dr. Wł. Biegańskiego w Grudziądzu. W celu wyeliminowania czynnika zmiany wartości pieniądza w czasie dane zostały skorygowane o inflację i wszystkie dane zostały sprowadzone do poziomu cen w 2015 roku.

Tabela 1. Zadłużenie Miasta Grudziądza oraz Regionalnego Szpitala Specjalistycznego im. dr. Wł. Biegańskiego w Grudziądzu w latach 2010-2015

\begin{tabular}{|c|c|c|c|c|}
\hline & & & \multicolumn{2}{|c|}{ w tym: } \\
\cline { 4 - 5 } Lata & $\begin{array}{c}\text { Zadłużenie } \\
\text { Miasta } \\
\text { Grudziądz }\end{array}$ & $\begin{array}{c}\text { Zadłużenie } \\
\text { RSS w } \\
\text { Grudziądzu }\end{array}$ & $\begin{array}{c}\text { Wobec } \\
\text { pozostałych } \\
\text { krajowych } \\
\text { instytucji } \\
\text { finansowych }\end{array}$ & Zobowiązania \\
wymagalne
\end{tabular}

Źródło: opracowanie własne

Dane zawarte w Tabeli 1 potwierdzają już sformułowane tezy, niemniej wskazują również, jak poważnym zagrożeniem dla bezpieczeństwa poszczególnych jednostek samorządu terytorialnego może być zadłużenie ich jednostek organizacyjnych. Dla wyjaśnienia dodać trzeba, że ujęte w tabeli „pozostałe krajowe instytucje finansowe” to 
Daniel Jurewicz - Ograniczona wartość poznawcza finansów...

popularnie zwane „parabanki” a „zobowiązania wymagalne” to zobowiązania, które nie zostały opłacone w terminie.

Obowiązujący system ewidencji i sprawozdawczości jest, niestety, mocno zawodny. Dane ilościowe pochodzące z budżetów oraz sprawozdawczości jednostek samorządu terytorialnego nie zawsze wiernie obrazują sytuację finansową samorządów. Dane te stanowią oczywiście ważne źródło informacji, niemniej, aby móc na ich podstawie wyciągać wiarygodne wnioski należy mieć wiedzę na temat ograniczeń i niedoskonałości z nimi związanych.

\section{Podsumowanie}

Zaprezentowane $\mathrm{w}$ niniejszym tekście informacje dają podstawę do sformułowania dwóch ważnych wniosków. Po pierwsze - i tak ułomna wartość poznawcza danych ilościowych może okazać się jeszcze mniejsza w odniesieniu do podmiotów publicznych, w tym jednostek samorządu terytorialnego. Po drugie - znaczna część kategorycznych twierdzeń zawartych w literaturze przedmiotu, mających swe oparcie w danych pochodzących z budżetów oraz sprawozdawczości jednostek samorządu terytorialnego może okazać się nieuzasadniona.

Potwierdzeniem mogą być wyniki wcześniej przeprowadzonych przez autora badań ${ }^{18}$. Literatura przedmiotu zawiera liczne badania wskazujące na bardzo silną, dodatnią, korelację między długiem a działalnością inwestycyjną polskich samorządów. Ze względu na ułomność klasyfikacji budżetowej oraz obowiązującego systemu sprawozdawczego inni badacze pomijają kwestie refinansowania (zwanego popularnie rolowaniem) długu na szczeblu samorządowym. Uwzględniając dane w zakresie refinansowania długu samorządowego autor zbadał zależność między zobowiązaniami zwrotnymi gmin województwa kujawsko-pomorskiego oraz ich działalnością inwesty-

18 D. Jurewicz, Dług samorządu - bodziec czy bariera absorpcji środków europejskich?, „Ruch Prawniczy, Ekonomiczny i Socjologiczny” 2016, nr 2, s. 231-249. 
cyjną w latach 2003-2013. Okazało się, że korelacja ma kierunek dodatni, niemniej jej siłę uznać należy za umiarkowaną, a nie bardzo silną, jak wskazują inni autorzy.

Przygotowany tekst z racji założonego rozmiaru publikacji ma charakter syntetyczny i uproszczony. Autor postanowił bowiem skoncentrować się na empirycznej części prezentującej skalę i charakter opisywanych zjawisk. Uwzględniając argumenty i dane przedstawione w tekście uznać należy, że dane zawarte w budżetach oraz sprawozdaniach jednostek samorządu terytorialnego bardziej niż precyzyjny obraz wskazują na tendencje występujące we wskazanych podmiotach. Oczywiście niniejszy tekst nie może aspirować do miana kompleksowego rozwiązania pojawiających się wątpliwości, autor ma jednak nadzieję, że może stanowić inspirację przynajmniej dla części badaczy zagadnień związanych z finansami publicznymi.

\section{Bibliografia:}

Babczuk A., Zadłużenie spółek komunalnych w Polsce. Próba oceny skali i zróżnicowania regionalnego „,Finanse Komunalne” 2012, nr 9, s. 5-16.

Curulis, Kondycja finansowa spółek komunalnych $w$ Polsce, http:/curulis.pl/ pliki/wiedza/20141030_raportspolkikomunalne_v13.pdf.

Czempas J., Skłonność jednostek samorzq̨du terytorialnego do inwestowania. Ujęcie ilościowe na przykładzie miast na prawach powiatu województwa ślq̨skiego, Wyd. Uniwersytetu Ekonomicznego w Katowicach, Katowice 2013.

Jurewicz D., Dług samorządu - bodziec czy bariera absorpcji środków europejskich?, „Ruch Prawniczy, Ekonomiczny i Socjologiczny” 2016, nr 2, s. 231249.

Kamela-Sowińska A., Sekurytyzacja jako metoda oddłużenia polskich szpitali, „Finanse, Rynki Finansowe, Ubezpieczenia” 2014, nr 67, s. 911-920.

Kołodko G. W., Społeczne i przestrzenne aspekty zróżnicowania dochodów we wspótczesnym świecie, „Nierówności Społeczne a Wzrost Gospodarczy” 2014, nr 39, s. 26-37.

Mączyńska E., Ekonomia w warunkach gospodarki nietrwałości, „Biuletyn PTE” 2011, nr 2, s. 35-47. 
Daniel Jurewicz - Ograniczona wartość poznawcza finansów...

Pietrzak B., Woźniak, B., Instytucjonalne aspekty konsolidacji finansów publicznych, „Zeszyty Naukowe Uniwersytetu Ekonomicznego w Krakowie” 2014, nr 8, s. 93-109.

Ratajczak M., Ekonomia $w$ dobie finansyzacji gospodarki, „Ruch Prawniczy, Ekonomiczny i Socjologiczny" 2014, nr 2, s. 259-271.

Roczne wskaźniki cen towarów i usług konsumpcyjnych od 1950 roku, http://stat.gov.pl/obszary-tematyczne/ceny-handel/wskazniki-cen/ wskazniki-cen-towarow-i-uslug-konsumpcyjnych-pot-inflacja/rocznewskazniki-cen-towarow-i-uslug-konsumpcyjnych-w-latach-1950-2016.

Tkocz-Wolny K., Harmonizacja i standaryzacja rachunkowości sektora publicznego, „Finanse, Rynki Finansowe, Ubezpieczenia” 2016, nr 4, s. 841850.

Wakuła M., Standaryzacja rachunkowości budżetowej, „Finanse, Rynki Finansowe, Ubezpieczenia" 2016, nr 2, s. 235-241.

Woźniak M. G., O niektórych problemach współczesnego człowieka, ekonomii i systemów ekonomicznych w kontekście integracji procesów rozwojowych, „Nierówności Społeczne a Wzrost Gospodarczy” 2015, nr 41, s. 195-213.

Zadłużenie Sektora Finansów Publicznych. Biuletyny Kwartalne za lata 20032013, Ministerstwo Finansów, Warszawa.

Ziółkowska W., Wybrane aspekty konsolidacji fiskalnej w sektorze general government, „Finanse, Rynki Finansowe, Ubezpieczenia” 2016, nr 6 cz. 2, s. 5-16. 